\title{
Manoeuvring between regulations to achieve locally accepted results: analysis of school meals in Latvia and Finland
}

\author{
Mikelis Grivins ${ }^{1}$ (D) Talis Tisenkopfs ${ }^{1} \cdot$ Ville Tikka $^{2} \cdot$ Tiina Silvasti $^{2}$
}

Received: 19 April 2018 / Accepted: 22 October 2018 / Published online: 14 November 2018

(C) The Author(s) 2018

\begin{abstract}
Rather than having a consistent food policy, countries often tend to regulate food from the margins of other policy domains such as agricultural, environmental, welfare or educational policies. Regulatory interventions perceive food as an instrument rather than a domain with its own specific set of policy issues and view food provision as an activity to achieve certain economic, social and environmental objectives. This fragments the food policy into disintegrated points of interventions from various policy areas and leaves unregulated voids that can be exploited either to improve or to reduce the effectiveness of the interventions. This article explores interlinkages between fragmented policies and regulations to offer a conceptual model linking regulated elements of the food system. The research is a multiple case study consisting of three cases: one Finnish and two Latvian. The aim of the study is 1) to expose the variety of perspectives used to set regulations for school meals and 2) to analyse how these regulations are aligned by the actors implementing them. The empirical data is composed of literature, regulatory documents, interviews, scenario workshops and media data. The results indicate that the key perspectives used to set regulatory interventions in both countries are entitlements, health and environment. However, actors implementing regulations have remarkable space for interpretation and manoeuvring.
\end{abstract}

Keywords Food policy $\cdot$ School meals $\cdot$ Policy implementation

\section{Introduction}

The vulnerability of contemporary food systems and the consequential threats to global food and nutritional security have forced researchers to look for ways to re-think and re-structure the practices dominating food systems (Marsden 2013). Calls for change have been echoed by prominent thinkers, supranational organisations, NGOs and even the food industry, which have urged policy-makers to rally to facilitate a shift towards a more self-reflexive and resilient industry (see Lang and Barling 2013, 2012; Ericksen et al. 2009; MacRae and Abergel 2016). Recent decades have also borne the first fruits of this turmoil. However, despite the growing number of

Mikelis Grivins

mikelis.grivins@gmail.com

1 Baltic Studies Centre, Kokneses prospekts 26-2, Riga LV-1014, Latvia

2 University of Jyväskylä, P.O. Box 35, Keskussairaalantie 2, 40014 Jyväskylän yliopisto, Finland success stories and the numerous discussions urging the regulation of food as a separate field, for the most part, the call to action has not managed to convince policy-makers. Food has not become a matter of its own policy in most countries. It is rather an instrument addressing problems faced by other politically well-established domains (see Lang et al. 2002; Foran et al. 2014). The journey calories make from farm to plate is guided by scattered clusters of regulatory interventions (Bradbear and Friel 2013).

Food systems governance has been divided into fields of responsibilities (influences) which have disintegrated regulatory interventions and in general created a simplified perception of issues that are associated with food. Consequential fragmentation is deeply institutionalised in the policies and in the structure of government departments and can be the cause of contradictive and inefficient regulations and the emergence of unregulated grey zones (areas in between the regulated aspects of the food system). For example, various aspects of school meal provisioning in Latvia - production processes (the supply side), expected nutritional characteristics of meals (the demand side), funding, transaction of ordering and buying the products and monitoring (control) of the 
final product - are all responsibilities of different political actors. Each of the actors pushes areas they are responsible for in different directions as they hold different framings on what the goals to be achieved are. Integrating these aspects of food flows into a coherent food policy would be a noteworthy challenge (Lang and Heasman 2004), something which is currently left to those implementing regulations (Sonnino et al. 2014).

This article analyses school meal provisioning to address the fragmentation of food regulations and to illustrate how actors implementing these regulations manoeuvre among them. The article has two goals: to identify the key frames that are used to set regulations for school meals and to use these frames to analyse how actors implementing the regulations align them. In the article school meals are used as an example for an arena where diverse regulations are aligned. The field of school meals is selected due to repeated suggestions that it has high potential to simultaneously facilitate changes at multiple food system levels (Sonnino et al. 2014): linking multiple levels of governance regulations of what and how pupils eat can support emergence of new or protect existing ways of doing things (facilitate shifts in dominating diets, encourage emergence of new ways of production, etc.), strengthen certain practices/products and improve their competitiveness outside the school, improve the health of pupils, etc. School meals are the point of crystallisation where different food interpretations are negotiated, which leads to at least partly shared agreement of what should be served and how (Keine and Brightwell 2015). The article analyses three cases from two countries: Latvia and Finland. It does not compare cases but rather uses them to underline the complexity of alignments leading to the practical ways school meals are organised. The frames that are used to classify regulatory interventions - entitlements, health and environment - have been based on the analysis of the regulatory frameworks in the two countries and that of theoretical literature discussing food regulations. The analysis of cases illustrates how the regulatory interventions are subordinated to values dominant among actors implementing the regulations.

This introduction is followed by a section that discusses the role competing frames have in creating new regulations. The section also explores major frames that guide the development of food regulations and illustrates how actors implementing regulations need to align various frames. The third section gives an overview of the data and methods used in this article. This is followed by the fourth section, which discusses school meal regulations in the two countries: Latvia and Finland. The section uses three frames - entitlements, health and environment - to classify the thinking behind regulatory interventions. The fifth section illustrates how the perspectives identified in the literature are aligned according to the vision of the actors implementing these regulations. To do this, three cases of school meal provisioning are analysed. Finally, the paper concludes with a section discussing the findings. The paper suggests that in between the frames there is a place that actors implementing school meal regulations can use to manoeuvre and that the final shape of how regulations are implemented reflects local involvement with food.

\section{Competing priorities}

Each political issue may have a number of ways by which it can be perceived. This serves as fertile soil for policy controversies to emerge (Falk 2007). For stakeholders involved in controversy it is a struggle to impose a particular framing over the issue domains (incorporating them into a particular paradigm), which means that actors compete to provide an explanation about the issue. It is crucial for these actors to secure the dominance of a particular framing; preferable and acceptable actions to resolve any issue emerge from the perception of the problem and the image it has (Schön and Rein 1994). With time, these frames can change and incorporate new ideas about how reality should be seen. However, on their own, at any given moment, they might be incompatible, and thus it might turn out to be impossible to introduce a description of a situation that would be satisfactory to all interested parties. Partly this is because frames constituting the controversy do not emerge with the issue; rather they represent broader constantly competing claims regarding how the world functions. As such, these claims do not necessarily reflect characteristics that are integral to the issue being solved, but rather they concentrate on aspects that are crucial for the frame.

Literature discussing food regulations identifies three sets of frames that have motivated policy-makers to engage with food: productionist, nutritional and environmental (Lang and Heasman 2004, 34). Overall, the three framings have set the tone for how food systems are seen; how their functionality is described and what key challenges are associated with food. Each of these frames are characterised by its ideological conflicts; they are represented by at least a partly separated field of stakeholders holding their unique targets and are surrounded by a circle of supporting governmental, professional and nongovernmental organisations, etc. The most commonly used frame to interpret food systems emerges from what Lang and Heasman (2004) call the productionist paradigm. The frame stresses under-consumption, under-production and poor distribution as key problems food system have to resolve (Lang and Heasman 2004, 34). Food, in this case, is approached through notions such as food security, socioeconomic equality and welfare (see Lang et al. 2002; Moragues-Faus et al. 2017; Timmer 2008; Grivins and Tisenkopfs 2015), yet food entitlements are seen as a significant policy instrument - everybody is entitled to food and the primary concern for policymakers is to facilitate the existence of more food at lower prices. Meanwhile, consumers are 
regarded as responsible both for the choices they make as well as for their own health, and thus little attention is paid to the quality of food. Overall, authors who refer to this paradigm tend to present it as a somewhat outdated way to look at food. This is mainly because of the narrow interpretation of challenges it associates with food systems and its focus on entrepreneurialism.

A distinct, yet strongly related, way policy makers have been framing food systems is by focusing on the nutritional side of food. This perspective emerges from rising concerns about the spread of unhealthy diets and malnutrition and the consequential prevalence of diet-related non-communicable diseases (Libman et al. 2015). Health is the central concern for regulations representing this frame (Timmer 2008; Lang et al. 2002; Moragues-Faus et al. 2017), and in this regard it could be claimed that the perspective is solving the issues neglected (or even created) by the productionist perspective. Finally, researchers also discuss food regulations framed by the environmental footprint the contemporary food industry leaves (Timmer 2008). Related to the concerns of how sustainable the current food supply networks are, these regulations tend to put restrictions on food production, packaging and waste. There are also numerous cases when the environmental concerns merge with questions discussing the fairness of trade and locality of supply chains (a direction that could be interpreted as an attempt to combine some parts of the environmental perspective with selected aspects of productionism) (Kleine and Brightwell 2015; Paloviita and Järvelä 2016).

For the most part research discussing political agenda setting has been looking at how consensus among the competing frames is achieved. However, this question is relevant only for the cases when consensus is the goal. Meanwhile, for questions that instead of being resolved are just regulated, consensus does not have to be achieved. Unless the frames are confronted, they can coexist. In cases like these the weight of aligning the regulations emerging from competing frames falls on the shoulders of actors implementing regulations; mainly local level governments. For local authorities the only way to overcome the fragmentation of food regulations is either by introducing an overarching frame that resonates with local needs and beliefs (Candel and Pereira 2017) or by introducing strictly technical regulations but without involving themselves in an evaluation of the overall goals of these interventions.

In the case of school meals, regulations must be transformed into a publicly available service. Decentralisation and inclusive/ reflexive implementation of regulations are often perceived as the most promising way to ensure effective arrangements that tap into local strength and avoid or solve local limitations (Kleine and Brightwell 2015, 136; Sonnino et al. 2014). In vertically decentralised countries, the flexibility local authorities might need to align regulations is intentionally created by national level policy makers (see Sonnino et al. 2014). However, flexibility can also emerge from voids (unregulated gaps) in between the regulations. Urban food strategies and councils' green and local food procurements are just a few examples of cases which illustrate that local level authorities can benefit from loose, intentionally decentralised or conflicting national or supra-national regulations. However, there is an even greater stack of evidence illustrating how even promising attempts to facilitate change can fail due to poor implementation by local authorities (Sonnino and McWilliam 2011; Moragues-Faus et al. 2017). Research illustrates that a lack of competencies, limited administrative resources, a lobby of powerful actors against changes and disbelief in positive outcomes can restrict local authorities' engagement (Testa et al. 2012).

Food system outcomes are determined by a complex set of factors scattered across the frames used to interpret food provisioning. Improvisation with trade-offs between these perspectives will shift the performance characteristics of food systems, which, in turn, will affect people's wellbeing (Moragues-Faus et al. 2017). This means that there is a pressing need for an analysis of the trade-offs in particular contexts (Lang et al. 2009). The perspectives identified correspond with the very real challenges food systems face and, as such, illustrate that each of these perspectives can serve as the starting point for broader change (Foran et al. 2014). This article suggests that the local response to the diversity of food regulations is rooted in locally shared ideas of what is important, and this can either facilitate or hamper overall intentions originally associated with the regulations.

\section{Methods}

The research design consists of three separate case studies: two from Latvia and one from Finland. This multiple case study does not aim to perform comparative analysis per se. Instead, the purpose is, first, to expose the variety of key perspectives used to set regulations for school meals and, second, to analyse how these regulations are aligned flexibly by the actors implementing them. As a method, a multiple case study is especially advantageous when the contexts of the chosen cases differ, as it allows the analysis of the data both within each situation and across situations and, hence, to understand the differences and similarities among the cases. Consequently, different national contexts of school meal provisioning enrich the research setting by exposing local standpoints in setting and implementing regulations.

The empirical data for each case are composed of literature, regulatory documents and interviews. In addition, scenario workshops were used in the Latvian cases and media data in the Finnish case. For a start, thematic analyses of literature discussing food regulations and regulatory documents were conducted to reveal the key perspectives (frames) used to set 
regulatory interventions. These key perspectives are entitlements, health and environment.

The analysis of policy documents in Latvia (described in section "4. School meals in two countries") has allowed capturing of the three perspectives of regulatory interventions entitlements, health and environment. To analyse how regulatory interventions connected to these perspectives are aligned among actors implementing the regulations, two cases were examined in-depth in Latvia: a regional, municipality led reorganisation of school meals and a parent initiated ecological school meals project in a private school. The data consist of 26 thematic stakeholder interviews. The interviewees were municipality representatives, leaders of NGOs and parent groups, civil servants from the state departments and ministries, teachers, agricultural advisors, food scientists and school employees. Further, two scenario workshops were organised to elaborate on the initial findings of the case studies and to discuss the future of the school catering. The research was carried out to address all key aspects of school meals and to incorporate opinions of all major stakeholder groups.

The Finnish case of resources for school meals explored a rather well known Finnish multi-actor initiative towards ecologically sustainable and socially responsible school meals (Jyväskylä 2017a). Analysis relied on media data and document analysis, as well as using in-depth interviews with key actors. School meals are a well-established and highly researched practice in Finland, and an abundance of policy documents and scientific literature is available on the perspectives guiding regulatory interventions related to school meals. Thus, much of the information needed for analysis was obtained by careful desktop study of secondary data.

\section{School meals in two countries}

To analyse how actors implementing school meal regulations align them, an analysis of interventions structuring the domain is needed. Using the three frames identified in the second section of this article, policy documents regulating school meals in the two countries have been analysed. The analysis has allowed the capturing of three perspective regulations representing - entitlements, health and environment (see Table 1). The perspective "entitlements" is used with the same meaning as "free school meals entitlements" in other research - it designates groups of pupils that are entitled to receive, free of charge, meals (or receive other support in school). The second perspective - health, designates regulations setting nutritional norms, the organisation of catering and regulations setting benchmarks for the quality of products. The third perspective - environment, designates environmental aspects addressed by public catering regulations.

Table 1 provides an overview of the central principles structuring school meal provisioning in the two countries.
The table illustrates the frames used to interpret school meals. Each frame and the regulations based on the particular frame are advocated and maintained by a slightly different group of stakeholders and are oriented to specific goals. The challenges of the three frames and interpretative approaches become apparent when they need to be aligned in implementing regulations, as one regulatory intervention can hamper the goals posed by other perspectives. For example, caterers operating in Latvia's schools have been claiming that, for some products they serve, it is challenging to find producers able to supply the requested amount for the right price (the quality requirements set by the Health frame conflict with the financial restrictions set by the Entitlements frame). This problem has become even more apparent with the GPP (Green Public Procurement) in place (the Environmental frame may conflict with the other two frames). Also, it has been reported in interviews that due to the tight dietary requirements, in many cases pupils do not recognise the taste of dishes served. Because of this, a considerable portion of meals go to waste, which means that the goals of both the entitlement and environment regulations are undermined.

In practice, parallel regulative frames in school meals mean that actors implementing regulations at the local administration level (which is a key governance level responsible for school meals delivery both in Latvia and Finland) are made to set priorities and align the policy implementation according to often contradicting priorities. This process could be seen as an equivalent of setting food strategies (however, without actually coming up with a strategy). This is what can be observed in Latvia: in some cases municipalities and schools use the cracks between regulations to involve stakeholders and to come up with a commonly acknowledged set of actions that correspond to local priorities. Meanwhile, in Finland the same possibility to skew the regulations due to intentional broadness is often incorporated into these regulations.

\section{Three practical attempts to align the regulations}

This section uses three examples to illustrate how food regulations are implemented. The examples examine how interlinkages that actors implementing regulations introduce to connect the frames can either strengthen the positive effects of school meals or can be the reason why some regulations fail. The first example 'Failed transition' presents a municipality that enthusiastically started looking for a way to improve the quality of school meals by making public health and healthy nutrition for children one of the municipal's long-term development priorities. But the initiative slowly fizzled out into inertia and failed to introduce real changes due to a lack of dedication and the skills needed to apply regulations skilfully and consistently. The second example 
Table 1 Regulatory frameworks in school meals in Latvia and Finland

\begin{tabular}{|c|c|c|c|c|}
\hline & & Entitlements & Health & Environment \\
\hline \multirow[t]{2}{*}{$\begin{array}{l}\text { Main } \\
\text { correspond- } \\
\text { ing } \\
\text { regulations }\end{array}$} & $\mathrm{LV}^{\mathrm{a}}$ & $\begin{array}{l}\text { Cabinet regulation No } 1206 \text { (Cabinet 2010). } \\
\text { Regulation states that pupils studying } \\
\text { from Year } 1 \text { to } 4 \text { are entitled to free meals } \\
\text { covered by the national budget (1.42 EUR } \\
\text { per pupil per day). }\end{array}$ & $\begin{array}{l}\text { Cabinet regulation No } 172 \text { (Cabinet 2012). } \\
\text { The regulation describes the nutritional } \\
\text { requirements of products and meals } \\
\text { served to pupils. }\end{array}$ & $\begin{array}{l}\text { Green Public Procurement (GPP) legislation. } \\
\text { Cabinet regulation No } 673 \text { (Cabinet 2014) } \\
\text { and official recommendations (VARAM } \\
\text { 2016). Regulation identifies the principles } \\
\text { that should facilitate that procurement is } \\
\text { more environmentally responsible. }\end{array}$ \\
\hline & FI & $\begin{array}{l}\text { Parliament regulations 628/1998 (Parliament } \\
\text { 1998a), 629/1998 (Parliament 1998b), } \\
\text { and 629/1998 (Parliament 1998c). All } \\
\text { pupils receive free of charge meals paid } \\
\text { by municipalities and other education } \\
\text { providers. The meals cost local authorities } \\
\text { anywhere from } 1.67 \text { to } 8.28 \text {. }\end{array}$ & $\begin{array}{l}\text { National Nutrition Council's (VRN) } \\
\text { guidelines for school meals (VRN 2008) } \\
\text { and national nutrition recommendations } \\
\text { (VRN 2014). The legislation states that, in } \\
\text { comprehensive schools, the meals should } \\
\text { be wholesome and appropriately } \\
\text { organised and tutored. }\end{array}$ & $\begin{array}{l}\text { Public Procurement legislation (Parliament } \\
\text { 2016), government resolution (Ministry } \\
\text { of Agriculture and Forestry 2016) and } \\
\text { official recommendations (Motiva } \\
\text { hankintapalvelu 2017). Regulations } \\
\text { instruct municipalities how to organise } \\
\text { procurement to address animal welfare } \\
\text { and health issues, food safety, } \\
\text { environmental impacts and social } \\
\text { responsibility. }\end{array}$ \\
\hline \multirow[t]{2}{*}{ Goal } & LV & $\begin{array}{l}\text { To ensure free wholesome meals for pupils } \\
\text { and to ensure equal access to food. }\end{array}$ & $\begin{array}{l}\text { Healthy food choices among inhabitants and } \\
\text { educating pupils on healthy nutrition. }\end{array}$ & $\begin{array}{l}\text { To ensure higher environmental standards } \\
\text { and to promote local food. }\end{array}$ \\
\hline & FI & & $\begin{array}{l}\text { Healthy food choices among inhabitants and } \\
\text { educating pupils on nutrition. Teaching } \\
\text { good manners and local food culture. }\end{array}$ & $\begin{array}{l}\text { To facilitate purchase of responsibly } \\
\text { produced foodstuffs and to promote } \\
\text { economic sustainability. }\end{array}$ \\
\hline \multirow[t]{2}{*}{ Main promoter } & LV & Ministry of Welfare, local authorities. & Ministry of Health. & Ministry of Agriculture. \\
\hline & FI & $\begin{array}{l}\text { VRN, Finnish National Agency for } \\
\text { Education. }\end{array}$ & $\begin{array}{l}\text { VRN, The Social Insurance Institution, } \\
\text { Ministry of Social Affairs and Health. }\end{array}$ & $\begin{array}{l}\text { Public Procurement Advisory Unit, Natural } \\
\text { Resources Institute Finland. }\end{array}$ \\
\hline \multirow[t]{2}{*}{ Implementation } & LV & At the municipal or school level. & At the municipal or school level. & At the municipal or school level \\
\hline & FI & $\begin{array}{l}\text { Implemented by school founders (mainly - } \\
\text { municipalities). }\end{array}$ & $\begin{array}{l}\text { Municipalities follow VRN guidelines but } \\
\text { still have a lot of space for manoeuvring. }\end{array}$ & $\begin{array}{l}\text { Implemented by municipalities that are } \\
\text { given space to introduce their own goals. }\end{array}$ \\
\hline \multirow{2}{*}{$\begin{array}{l}\text { Actors } \\
\text { contesting } \\
\text { regulations }\end{array}$} & LV & None. & $\begin{array}{l}\text { Ministry of Agriculture, producer groups, } \\
\text { consumer groups. }\end{array}$ & $\begin{array}{l}\text { Ministry of Health, wholesalers and some } \\
\text { other entrepreneurial groups. }\end{array}$ \\
\hline & FI & $\begin{array}{l}\text { Parents (Ravintotietoiset vanhemmat } \\
\text { (Nutrition wise parents) Facebook group, } \\
\text { which is a group for parents who are } \\
\text { against the national nutrition } \\
\text { recommendations. }\end{array}$ & $\begin{array}{l}\text { Parents, some municipalities, self-appointed } \\
\text { online nutrition professionals and } \\
\text { bloggers. }\end{array}$ & None. \\
\hline \multirow[t]{2}{*}{ Issues faced } & LV & $\begin{array}{l}\text { - insufficient funding to provide quality } \\
\text { meals; } \\
\text { - geographical inequality among } \\
\text { municipalities - wealthier municipalities } \\
\text { invest to ensure meals of higher quality } \\
\text { for more pupils; } \\
\text { - due to guaranteed customers, caterers lose } \\
\text { their motivation to ensure quality; } \\
\text { - high amount of food waste. }\end{array}$ & $\begin{array}{l}\text { - quality demands might be hard follow (due } \\
\text { to inapposite infrastructure); } \\
\text { - pupils are not used to products described in } \\
\text { guidelines (food neo-phobia); } \\
\text { - there are claims that producers are unable to } \\
\text { provide products mentioned in guidelines; } \\
\text { - regulations put many school cafeterias out } \\
\text { of business. }\end{array}$ & $\begin{array}{l}\text { - some actors believe that economic and } \\
\text { environmental factors promoted by the } \\
\text { GPP interests overshadow health needs; } \\
\text { - local administration lacks the experience, } \\
\text { resources and often motivation to } \\
\text { implement GPP; } \\
\text { - government agencies do not have the } \\
\text { means to control the execution of GPP; } \\
\text { - relatively little information is available } \\
\text { about the possible suppliers. }\end{array}$ \\
\hline & FI & $\begin{array}{l}\text { - pupils not utilising the free meals, } \\
\text { especially teenagers in secondary schools } \\
\text { in higher levels (a gendered issue as well); } \\
\text { - high amount of food waste; } \\
\text { - different quality of meals in municipalities } \\
\text { with different wealth levels. }\end{array}$ & $\begin{array}{l}\text { - national guidelines face heavy criticism. } \\
\text { - contesting diets. }\end{array}$ & $\begin{array}{l}\text { - municipalities centralise procurement; } \\
\text { - procurement legislation is not used to its } \\
\text { full potential (emphasising qualitative } \\
\text { aspects over price); } \\
\text { - engagement of municipalities differs; } \\
\text { - level of local and/or organic produce does } \\
\text { not necessarily suit the needs of large } \\
\text { caterers (wholesalers are dominating the } \\
\text { supply side). }\end{array}$ \\
\hline
\end{tabular}

${ }^{\mathrm{a}}$ In the table abbreviations are used to denote a country - LV for Latvia and FI for Finland

${ }^{\mathrm{b}}$ Actors challenging formulations and requirements formulated in regulations

'Striving for sustainable diets, wellbeing and ownership' illustrates a parent led private school project that, soon after its establishment, identified sustainable food along with ecological education and community participation as its priorities. The project has been successfully using and combining various regulations to develop the delivery of organic meals, an organic kitchen and a school garden through deep engagement and interaction among parents, teachers, cooks, organic farmers and the local community. However, the case also illustrates how the school's attempt to prioritise a particular 
frame has led it into open conflict with the other two framings and how the experience of this particular school triggered nation-wide discussions about the needed changes in the school meals system. The third case 'Resource Wise School Lunch' exemplifies an emerging practice to connect in a socially and an environmentally sound way to prevent food waste in school canteens.

\section{1 'Failed transition'}

The case of a failed transition serves as an example of how competition between frame changes the priorities that actors organising school meals might have. The representatives of the municipality in the example here did not think much about public food procurement up until 2011. Then the municipality was invited to participate in an international project where it was offered both intellectual and financial support to develop a food strategy. The municipality was keen to join the project. It was the years of economic crisis, and economic difficulties were still felt harshly in Latvia's countryside. Thus, food strategy was at least partly seen as an innovative way to assist local producers. With the support of researchers, multiple workshops were held where stakeholders had the opportunity to discuss the goals the municipality should associate with food. The resulting food strategy suggested that the municipality should improve the quality of food, which according to the strategy could be achieved by improving the nutritional characteristics of food available in the municipality (health perspective), by strengthening local producers and by organic production methods (environmental perspective). Back then some municipal deputies already appeared to be sceptical about the need for a local strategy to discuss the role of food. Despite this, the support the municipality received from experts located outside the municipality allowed local enthusiasts to ignore the critique.

The strategy identified public procurement as the main instrument to facilitate change. Still, the contracts with the catering service already operating in schools were signed in 2011 and were granted the enterprise exclusive rights to operate in municipal schools for the next 5 years. In fact, all the largest municipal schools were supplied by one prominent local caterer. However, a group of smaller schools had inhouse cooks and were not bound by the 5-years contract. Finally, in 2014 the municipality was ready to test its good intentions in procurement, and the smaller schools were able to source food products locally. The municipality was well prepared and introduced in the procurement process requirements that gave an advantage to local and organic producers. The criteria set by the municipality received one complaint from the largest product supplying company in Latvia, which after quick consultations with The Procurement Monitoring Bureau was rejected.
Meanwhile, word of the municipality's efforts reached other stakeholders holding a particular interest in food. Just before the announcement of the procurement in 2014, the Latvian Rural Advisory and Training Centre (LRATC), while looking for arguments to convince Latvia's municipalities to help local small enterprises, ordered an assessment of the economic benefits associated with local product procurement (Korpa et al. 2015). Strategically, the municipality's case was chosen. The results of the study were released soon after the procurement results were announced. The study has been criticised for its quality: however, it reassured the actors involved that buying locally could improve local economies. In light of these findings, LRATC promised to assist municipalities and help them to overcome practical challenges that might arise from participating in school food procurement.

The procurement in 2014 was comparatively small and amounted to around 270,000 euros. However, $67 \%$ of this money went to local farmers. For the municipality it was a success - in the previous product procurement held in 2013 only around $25 \%$ of money went to local suppliers. Still, some groups felt differently; only few of the procured products were organically certified, few truly small producers participated and no new producers' cooperatives were established. These problems could be resolved in the product procurement held in the following year. However, in 2015 new procurement regulations were released that raised the procurement threshold for public green purchases to 42,000 EUR. Most of the small schools, if considered separately, paid less for the required products. This was an opportunity to shift to truly local procurement. The municipality decentralised its procurement by giving the small local schools the mandate to buy for themselves the products they need. In a truly bureaucratic approach, once the function of supplying the products was allocated, the municipality lost its interest in these schools. However, the following year revealed that the small schools were poorly equipped to negotiate with product suppliers on their own; they lacked the competencies and resources. Schools came back to the municipal authorities and asked to be included in the joint catering procurement process. The number of schools with in-house cooking decreased, while the number of schools participating in the joint catering procurement grew. The very technical approach the municipality had in executing its plans led to a failure to benefit from the resources it already had; small school with established links to local producer communities.

The municipality's next opportunity to follow its food strategy was the procurement scheduled for 2016. The procurement covered most of the municipality's schools, with the planned order exceeding a million Euro. Yet, when the municipality's representative responsible for school meals was interviewed in 2016 she stated that the municipality had dropped the unrealistic goals to procure local or organic products. This decision was most likely a result of the close 
relations the municipality's deputies had with the caterer operating in schools at the time. The claim was that the new goal was to revitalise the nutritional side of school meals by introducing greater accountability of the caterer and to facilitate dialogue among pupils, parents and the caterer. This represented a significant shift in terms of what the municipality wanted to achieve, yet it still captured at least some priorities identified in the strategy. However, in the interviews conducted in 2017 , another representative of the municipality revealed that none of these ideas was implemented in practice, and schools were still being catered by the same large caterer. In fact, the caterer was now supplying food to a greater number of schools. Meanwhile, the products the caterer used were supplied by just one large logistics enterprise.

So what happened? The years following the successful procurement in 2014 illustrated that the municipality and the LRATC had insufficient interest, knowledge and support to actually create conditions of procurement which favoured local producers that could sustain itself. Furthermore, the funding provided by the international project had been spent, and with the absence of a clear leader the idea was slowly disappearing. When it came to the introduction of these ideas in practice, it turned out that they were not supported by local deputies. Official rhetoric claimed that these fancy ideas were what some small groups of people wanted, and that they did not represent the interests of the local population who were perfectly fine with the catering already provided in schools. Indeed, having financial support from outside the municipality, those who advocated for a more responsible procurement never bothered to ensure that they had the support from local communities. Furthermore, it was easy for the municipality to ensure meals for the pupils studying in the largest schools. However, the smaller schools, once they stopped organising their own catering, faced difficulties in attracting enterprises willing to provide meals. For caterers these schools were liabilities rather than places where profit could be made; they were just too small to be profitable. In this context it was convenient for the municipality to centralise the procurement by bundling the profitable and un-profitable schools together. Thus, the need to ensure entitlements overshadowed attempts to improve the healthiness or environmental performance of the meals. Due to this, as well as due to some procurement requirements which could be interpreted as indications that the municipality might have been inclined to continue to collaborate with the caterer already operating in the local schools, only two proposals were received. One proposal was identified as non-compliant with the requirements and thus was not evaluated at all. This left the municipality with just one proposal, which had been submitted by the caterer already working in municipal schools. When the results of the procurement were officially announced it was almost the new study year, and the municipality was in a rush to sign the contract without negotiating any special supervision aspects. Thus, at this point even the ideas of additional accountability had been lost. Despite the dynamic events and the push for change between the two waves of procurement, the end results were the same and even a little worse than they were before.

\section{2 'Striving for sustainable diets'}

The case of sustainable diets presents a private school's attempt to convert from conventional to organic vegetarian school meals that was challenged by the State Food and Veterinary Service (FVS) as incompliant with nutritional regulations: 'We need to bring changes that we want to see in the world' was the slogan guiding the founding of a school in 2010 in a town located around $30 \mathrm{~km}$ from Riga. A group of highly educated and well-situated parents founded the school and were willing to provide for their children a different kind of education; one more involved and responsible, less structured and demanding. Being a place created by active citizens (many of whom held beliefs incompatible with the conventional education system), the school quickly grew in terms of functions it worked with. Already from the beginning it was claimed that children should learn more about and from nature, should maintain the Latvian cultural heritage and should be looking at complex moral and philosophical issues. Food naturally emerged as one the aspects where these themes overlapped. Furthermore, with the school being open to its surroundings acted like a sponge and absorbed various initiatives emerging in the town. Early on, it established a garden that was maintained according to the principles of permaculture, and it did the following: became a focal point where local direct buying could operate, established a pop-up restaurant, created a seed bank, attracted a highly qualified cook, became a member of the Eco-School movement and became a pioneer by providing its pupils with vegetarian meals. However, despite the complex web of food initiatives surrounding the school, the school on its own was not looking for a way to change the food system. Instead, it aimed at creating critical and responsible youth.

Although started as separate activities, most of the initiatives the school is involved in have turned out to be complementary. Seeds stored in the school were planted in the garden and the garden provided some of the products used in the daily meals, while other products were obtained through direct buying from farmers. Participation in the Eco-School movement is a motivation to monitor food waste, while the pop-up restaurant served as an opportunity for parents to gather in the school and to try the meals their children ate on a daily basis (at these events children were involved in cooking and serving the meals).

In its first year the school did not have its own kitchen, and the meals were delivered from a neighbouring school. However, it was not long before the school managed to attract EU funding to build a kitchen, but they still could not afford 
all the equipment that would be officially required to store and cook meat. Thus, after consulting with parents, the school decided to offer only vegetarian meals. In the interview with representative of the school they claimed that both the school and the parents quickly realised the benefits of serving vegetarian meals; it allowed the serving of meals for affordable prices that were morally acceptable to everybody and that were organic, local and healthy. Depending on the age of the pupil, the monthly payments for the food per pupil was between 20 and 40 euro. For younger pupils, part of the costs was covered by the state. This price is close to the price that pupils would have to pay for their meals in municipal schools. Since then the school has invested in kitchen equipment but it has decided to stick with vegetarian meals.

Practically speaking, ensuring organic vegetarian meals for affordable prices requires the investment of a lot of labour. Around one-third of the products used in catering were grown in the school's garden, which is currently undergoing an organic certification process. The garden is maintained by parents, pupils and school staff. In order to store the harvests, the school has used EU funds to buy two freezers and has used its own resources to renovate the school's basement where vegetables are preserved for winter. Meanwhile, around twothirds of products used in meals are bought through direct buying. The school also hired a nutrition specialist to develop optimal vegetarian menus so that the children would receive all the vitamins they needed. The approach requires considerable planning and puts a lot of work on the shoulders of the cook. However, parents and teachers have shown that in order for this to work, they are willing to invest their time in assisting the kitchen personnel.

The school has put a great deal of effort into ensuring that the system functions. However, the solution introduced open conflicts with national guidelines for nutritional norms (see Cabinet 2012). Cabinet regulations state that all pupils should have their weekly portion of meat (the daily requirement of meat depends on the pupil's age). The school has been serving vegetarian meals to pupils since 2011, and for 5 years nobody seemed to care about this choice; serving vegetarian food was the way that the school could follow its environmental and health goals while securing accessibility of the meals for everybody. This changed in 2016 when the FVS inspected the school and ordered it to pay a 50 EUR fine for breaching regulations and to introduce meat onto the menu. The fine was clearly symbolic, yet it clearly illustrated that the FVS would not tolerate any improvisation with the set norms. FVS argued that parents' preferences cannot repeal national regulations. Meanwhile, during an in-depth interview a school representative recalled that the FVS unofficially suggested that the school should talk to doctors so that the parents might know to ask them for a medical report stating that the school's pupils should not eat meat. The FVS pushed the issue of various diets into the shadows by suggesting that vegetarian meals are acceptable only if parents are willing to label their children in official reports as ill. The school chose to follow a different route and sued the FVS. The principal of the school claimed on national TV that the real problem is that the school serves vegetarian meals openly. According to her, many schools were doing it, yet publicly they were pretending that they were not (Vìtola 2016) (armed with references from their doctors these schools were pretending that their pupils were ill). The school was ready to fight for a change in the system.

Some of the parents of pupils studying at the school were lawyers and were keen to assist their school in this complicated matter. Consequently, the school won the case against the state institution, and this on its own was something that had not happened before. However, the decision of the Administrative District Court only had the power to lift the fine, but it could not withdraw regulations. Not satisfied with the results, the FVS appealed the case. The school answered by saying that it is ready to take their case to the European Court of Human Rights.

The court had invited multiple nutritional organisations to provide their opinion of whether meals without meat could provide all the nutrients needed by a child. So far, independent experts have expressed their support for vegetarian menus by claiming that the existing regulations promote an outdated perspective on what is a meal and that vegetarianism should be introduced as an opt in for school meals (Pētersone 2017). Despite this, the school lost the appeal. Meanwhile, the Ministry of Health, the organisation that developed the original health regulations, has been remarkably silent on the issue. It claimed that it is following the case and will change the regulations if needed.

\section{3 'Resource Wise School Lunch'}

The case of what constitutes a good school lunch addresses an increasingly burning issue on food waste as a by-product of school meals. The example examines initiatives led by local government actors that are aimed at reduction of food waste in school catering. The unconsumed food in school canteens and by other food service actors poses a problem which has been documented in a number of studies (Silvennoinen et al. 2012; Silvennoinen et al. 2016). Some studies suggest that in Finland up to $28 \%$ of cooked meals are wasted (Silvennoinen et al. 2016, 187). In schools, the amount is lower than average, less than $20 \%$. Looking more closely at the food wasted in schools, $2 \%$ of all waste is kitchen waste and $5 \%$ is left unconsumed by diners, which means that the amount of salvageable food waste available for redistribution is just over $10 \%$ of all meals (Silvennoinen et al. 2012, 31).

Jyväskylä, a city in Central Finland, has adopted principles of so-called Resource Wisdom as its operational guideline. Resource Wisdom aims to establish a scalable operating model for cities to develop their regional economy and to create sustainable well-being from a circular and carbon-neutral 
economy. Jyväskylä aspires to an operational model where economic success can be found through responsible actions that are not only sustainable but that also increase well-being in the city (Jyväskylä 2017a). In the spirit of Resource Wisdom, a group of environmentally conscious personnel of Jyväskylä's public utility institution responsible for public catering (Kylän kattaus) came together to address the food waste issue in school catering. They were inspired by the ideas of a circular economy, food justice, entitlement to food, the improved management of food waste and solidarity with groups of the population that may experience difficulties in accessing food, even though some of the food is being regularly wasted in school canteens.

As a result, in 2013, some schools in the municipality started to experiment selling meals not consumed by children to other customers from the area. The price of a meal was set at only 1.50 EUR per portion to enable potentially food insecure people from the community to access nutritious and well prepared meals which otherwise would have been wasted (Jyväskylä 2017b, c). The experiment was advertised in housing areas where the population's income level was low (Jyväskylä 2017b). This experiment has since continued in seven of the region's schools under the name 'Resurssiviisas lounas' (Resource Wise Lunch) (Jyväskylä 2017c). The Jyväskylä school initiative for preventing food waste was gradually picked up by other towns and municipalities that saw the value of the initiative both in terms of its contribution to community and its ability to reduce the amount of food waste (for other examples see Arkea Oy 2017; Heinonen 2015; Municipality of Tyrnävä 2015; Pori 2017; Pölönen 2017; Servica 2017; Tuusula 2017.).

The organisation of surplus meals in Jyväskylä is simple: after lunch time, the schools indicate whether there are surplus meals available by pinning a note - either colour coded (green or red) or in a large enough font size - to the outside entrance of the canteen or school, which can then be easily read from a distance and which clearly informs if there is surplus food available. In Jyväskylä, initial experiments were conducted only in schools where the canteens had an outside entrance, as it was considered a possible security issue to allow visitors in other parts of the schools during school hours. In addition, a member of the staff was to be present during surplus lunch distribution to oversee the activity.

The nutritional qualities of surplus food should, to some extent, meet the guidelines set by the National Nutrition Council (VRN), though there have not been studies on the nutritional values of the actual meals provided. Being surplus food, the meals will often consist of only a portion of what has been prepared for school goers, which could mean that it is near impossible to provide a wholesome, guideline-meeting meal every day and to every customer. In addition, not all food waste meets the strict regulations for food redistribution. Food safety is strictly monitored in school canteens, and these regulations not only pose challenges to, and to some extent guide, the process of food surplus redistribution, but also they ensure that the food served as 'Resource Wise' lunches is just as safe as it was when it was first served to pupils. Still, despite the challenges to stay in line with national level guidelines, the initiative has the support of local authorities that allows it to interpret some of the regulatory requirements more loosely.

Several factors lay behind the success and social recognition of the Jyväskylä initiative: enthusiastic staff working in school meals led by an active service manager in Kylän Kattaus, the 'Resource Wisdom' ethos as an enabling operational environment and suitable school canteen facilities. The social acceptance is based on proposing solutions for two important food system challenges: the management of food waste (environmental perspective) and the situation of and help for foodinsecure groups (entitlements perspective). However, the initiative has also raised some criticism, mainly from local, lunch serving restaurants. These private sector actors argue that selling surplus food at a nominal price creates distortion of competition in the region. This argument was later refuted by the City Counsel of Jyväskylä. (see e.g. Yle 2013.) The experiment also faced challenges and ultimately failed in the region's care for the elderly, as many potential diners postponed having lunch in the canteen in order to access the discounted surplus alternative later the same day (Melville 2017).

To summarise, the city level guidelines of Resource Wisdom enabling the operational environment made the initiative concerning Resource Wise School Lunches possible. Key people working in the leading positions in the public utility institution responsible for public catering were environmentally conscious as well as committed to the principles of Resource Wisdom. In addition, they had the urge and capacity to start the operation. Because of security regulations there were also some requirements for the facilities where leftover food could be sold: there has to be a separate entrance to the canteen and there should always be a member of the personnel to supervise the operation, although this can be worked around, e.g. by utilising associations to distribute the meals, as some towns have done.

Starting the initiative required the reinterpretation of the basic idea of school meals. In the framework of prevailing norms and regulations, surplus food, which was earlier interpreted as food waste, was turned into edible nutritious food for the new focus group of clients. The reinterpretation of prevailing rules is not an actual innovation. Instead, the novel insight was to construe leftovers also as valuable food after the primary customers, i.e. school goers had left the canteen. In addition to environmental concerns and prevention of food waste, there was a social aspect of entitlement to food included in the operation. Healthy, nutritious, surplus food was especially advertised at the community level for people at risk of food poverty. Consequently, Resource Wise School Lunch provides a socially and environmentally sustainable practice to prevent food waste in school canteens. 


\section{Discussion and conclusions}

This article is based on two claims: first, food systems are regulated by scattered interventions rather than unified policy and, second, actors implementing these diverse regulations need to align them. To illustrate these two statements the article focuses on the organisation of school meals in Latvia and Finland: the article maps the regulatory interventions for school meals in the two countries and analyses three cases of school meal organisation.

The article combines results from an analysis of the regulations of national school meals with findings from the analysis of theoretical literature to introduce three frames motivating interventions in food systems. Three cases are used to illustrate how the actors involved have organised school meals and to show how the frames were aligned when implemented. The first case followed the municipality as it manoeuvred among the framings of school meals. Initially the municipality pursued an environmental perspective in the hope that it would help to support local entrepreneurs. Later on it shifted its interests to the health perspective by choosing a simpler alternative for its initial goals. Finally, in order to be able to maintain food entitlements, the municipality dropped its original intentions and outsourced school catering to a catering company. The second case illustrates a school that focused on the health dimension of food and linked it with environmental concerns in order to enhance the performance of both perspectives. The schools strived for organic and vegetarian diets, but the chosen path has put the school in open conflict with the state authorities. Finally, the third case indicates the importance of the city level commitment to the principles of so-called Resource Wisdom. Resource Wisdom aims to create sustainable well-being from a circular and carbon-neutral economy. Moreover, it is in tune with the Sustainable Development Goals in whichthe UN adopted a target of halving per capita food waste by 2030 .

Local actors are shaping the practical implementation of national regulations of school meals. These actors might not be following some clearly formulated strategies, rather their governing decisions are influenced by particular local interests, the values of certain stakeholders and the administrative or civil capacity of stakeholders to adapt and enforce regulations. In most cases actors align with regulations according to their understanding of what is important. In the cases presented here, actors implementing school meal regulations have the space to manoeuvre. The results achieved depend on what they decide to do with this ability. By manoeuvring, these actors create their own set of rules in regard to how government regulations are put into place and operated in practice at the local and regional level. For example, in the failed transition case, the municipality incorporated in GPP a clause that greatly reduced competition and sacrificed the environmental and health outcomes of school meals. However, it ensured entitlements even in the most distant rural schools. The Finnish example and the vegetarian meal case suggest that local level governance and alignment of various food system stakeholders is critical for solving most food related problems.

The cases presented underline that networks of actors supporting particular alignments in school meal governance at the local, municipal or city levels are of particular importance to understanding the way regulations are implemented. The private school example illustrates the role of motivation, knowledge and commitment of civil society members in food and nutrition issues, which allowed the school to mobilise various resources to enable particular alignments. Meanwhile, the Latvian municipality case suggests how the inability to develop functional supporting networks and neglecting the initiatives of civil servants can lead to simplified solutions in school meal delivery at the expense of children's free choice of eating healthy and tasty meals. It is important that in all cases the actual alignment of environmental, social and health concerns is dependent on stakeholders' ability to adjust and apply national and international regulations to local conditions and development priorities.

This article discusses the regulations that are explicitly oriented towards regulating aspects of school meals. However, all these regulations have a direct impact on the ways pupils interact with food. Furthermore, school is just one context, which shapes children's food habits, and there are other, equally important, contexts: family, peers, food industry, media, advertising and informal food education. There are also other regulations of crucial importance to understand the food decisions made by children themselves.

Acknowledgements The research was carried out in the framework of TRANSMANGO and funded by the European Union's FP7 Research and Innovation Programme under grant agreement No 613532.

\section{Compliance with ethical standards}

Conflict of interests The authors declare that they have no conflict of interest.

Open Access This article is distributed under the terms of the Creative Commons Attribution 4.0 International License (http:// creativecommons.org/licenses/by/4.0/), which permits unrestricted use, distribution, and reproduction in any medium, provided you give appropriate credit to the original author(s) and the source, provide a link to the Creative Commons license, and indicate if changes were made.

\section{References}

Arkea Oy. (2017). Arkea ja Hope ry jakavat koulujen ylijäämäruokaa vähävaraisille lapsiperheille Turussa. http://arkea.fi/fi/uutiset/201709-22 arkea-ja-hope-ry-jakavat-koulujen-ylij\%C3\%A4\%C3\% $\mathrm{A} 4 \mathrm{~m} \% \mathrm{C} 3 \% \mathrm{~A} 4 \mathrm{ruokaa}-\mathrm{v} \% \mathrm{C} 3 \% \mathrm{~A} 4 \mathrm{~h} \% \mathrm{C} 3 \% \mathrm{~A} 4 \mathrm{varaisille}-$ lapsiperheille. Accessed 16.12.2017.

Bradbear, C., \& Friel, S. (2013). Integrating climate change, food prices and population health. Food Policy, 43, 56-66. 
Cabinet. (2010). Kārtỉba, kādā aprēķina, piešksir un izlieto valsts budžetā paredzētos līdzekḷus pašvaldībām pamatizglìitỉbas iestādes skolēnu ēdināšanai. Cabinet of Ministers Regulations 1206. Issued on 28 December, 2010.

Cabinet. (2012). Regulations Regarding Nutritional Norms for Educatees of Educational Institutions, Clients of Social Care and Social Rehabilitation Institutions and Patients of Medical Treatment Institutions Republic of Latvia Cabinet Regulation No. 172, Riga, 13 March 2012. Available at: https://likumi.lv/doc.php?id=245300.

Cabinet. (2014). Noteikumi par vides kritēriju piemērošanu un piedāvājuma izvēles kritēriju noteikšanu pārtikas produktu piegādes un ēdināšanas pakalpojumu iepirkumiem. Cabinet of Ministers Regulations 673. Issues on 28 October, 2014.

Candel, J. J. L., \& Pereira, L. (2017). Towards integrated food policy: Main challenges and steps ahead. Environmental Science and Policy, 73, 89-92.

Ericksen, P., Ingram, J. S. I., \& Liverman, D. (2009). Food security and global environmental change: Emerging challenges. Environmental Science and Policy, 12(4), 373-377.

Falk, D. (2007). Policy framing in the European Union. Journal of European Public Policy, 14(4), 654-666.

Foran, T., Butler, J. R. A., Williams, L. J., Wanjura, W. J., Hall, A., Carter, L., Carberry, P. S., et al. (2014). Taking complexity in food systems seriously: An interdisciplinary analysis. World Development, 61, 85-101.

Grivins, M., \& Tisenkopfs, T. (2015). A discursive analysis of oppositional interpretations of the agro-food system: A case study of Latvia. Journal of Rural Studies, 39, 111-121.

Heinonen, E. (2015). Ylijäämäruoan myynti kouluilla jatkuu. http://www. riihimaki.fi/ylijaamaruoan-myynti-kouluilla-jatkuu/. Accessed 16. 12.2017 .

Jyväskylä (2017a). City of Jyväskylä: At the forefront of developing regional economy and sustainable well-being through Resource Wisdom. http://www.jyvaskyla.fi/international/news/1/0/82868. Accessed 14.12.2017.

Jyväskylä (2017b). Ruoanjakelijasta palvelulinjastoon - ruokapalvelun vuosikymmenet. https:/www.jyvaskyla.fi/instancedata/prime product julkaisu/jyvaskyla/embeds/jyvaskylawwwstructure/95150_Suomi100_ osa_9_2010-luku_002_.pdf. Accessed 12.08.2018.

Jyväskylä (2017c). Resurssiviisas lounas. https://www.jyvaskyla.fi/ ruokapalvelu/koulut. Accessed 14.12.2017.

Kleine, D., \& Brightwell, D. G. M. (2015). Repoliticising and scaling-up ethical consumption: Lessons from public procurement for school meals in Brazil. Geoforum, 67, 135-147.

Korpa, V., Siliņa, L., Šulce, G. (2015). Vietējo ražotāju produkcijas īpatsvara palielināšana pašvaldības publiskajos pārtikas produktu iepirkumos: situācijas analīze Tukuma novadā. http://new.llkc.lv/system/files_force/ aktualitates/petijums.pdf?...1. Accessed 12.08.2018.

Lang, T., \& Barling, D. (2012). Food security and food sustainability: Reformulating the debate. The Geographical Journal, 178(4), 313-326.

Lang, T., \& Barling, D. (2013). Nutrition and sustainability: An emerging food policy discourse. The Proceedings of the Nutrition Society, $72(1), 1-12$.

Lang, T., \& Heasman, M. (2004). Food wars: The global battle for mouths, minds and markets. London: Earthscan.

Lang, T., Barling, D., \& Caraher, M. (2002). Food, social policy and the environment: Towards a new model. Social Policy and Administration, 35(5), 538-558.

Lang, T., Barling, D., \& Caraher, M. (2009). Food policy: Integrating health, environment \& society. Oxford: Oxford University Press.

Libman, K., Freudenberg, N., Sanders, D., Puoane, T., \& Tsolekile, L. (2015). The role of urban food policy in preventing diet-related noncommunicable diseases in Cape Town and New York. Public Health, 129, 327-335.

MacRae, R., \& Abergel, E. (2016). Food policy in Canada: Reference module in food science. Oxford: Elsevier.
Marsden, T. (2013). From post-productionism to reflexive governance: Contested transitions in securing more sustainable food futures. Journal of Rural Studies, 29, 123-134.

Melville, P. (2017). Hukkalounas - koulun lounaitten ylijäämäruoka alueen vähävaraisille asukkaille. https://www.kokeilunpaikka.fi/fi/ experiment $/ 77 /$. Accessed 16.12.2017.

Ministry of Agriculture and Forestry. (2016). Government Resolution on the criteria for awarding public food and catering services (environmentally friendly crops, production conditions conducive to food safety and animal welfare). 29.06.2016.

Moragues-Faus, A., Sonnino, R., \& Marsden, T. (2017). Exploring European food system vulnerabilities: Towards integrated food security governance. Environmental Science and Policy, 75, 184-215.

Motiva hankintapalvelu. (2017). Guide for responsible procurement of food: recommendations for requirements and evaluation criteria. Version 1.0. Published 3/2017. December 7, 2017. Available at: http://www. motivanhankintapalvelu.fi/files/866/Guide_for_Responsible Procurement_of_Food_Final_pieni.pdf. Accessed 16.12.2017.

Municipality of Tyrnävä (2015). Ylijäämäruoan myynti pilottikokeiluna/ Murron koulu ja Kirkkomännikön koulu. Technical services committee minutes 2/2015, 25-26. Available at: http://docplayer.fi/ 12605433-Tyrnavan-kunta-poytakirja-2-2015-20.html. Accessed 16.12.2017.

Paloviita, A., \& Järvelä, M. (2016). Climate change adaptation and food supply chain management. Oxon: Routledge.

Parliament (1998a). Perusopetuslaki (The Basic Education Act). 21.8.1998/628

Parliament (1998b). Lukiolaki (The General Upper Secondary Schools Act). 21.8.1998/629.

Parliament (1998c). Laki ammatillisesta koulutuksesta (The Vocational Education and Training Act). 21.8.1998/630.

Parliament (2016). Lakijulkisista hankinnoista ja käyttöoikeussopimuksista (Law on Public Procurement and Licensing). December 29, 2016.

Pētersone, I. (2017). Par veǵetārismu - sods un tiesas process. Available in: http://www.la.lv/par-vegetarismu-sods-un-tiesas-process/. Accessed 12.08.2018.

Pölönen, K. (2017). Kuntastrategia luo perustan yhä edistyksellisempään Hollolaan. Kuntastrategia-blogi, 17.10.2017. https://www.hollola.fi/ kuntastrategia-luo-perustan-yha-edistyksellisempaan-hollolaan. Accessed 16.12.2017.

Pori (2017). Se mikä ennen oli ruokahävikkiä, on nyt hävikkiruokaa! https://www.pori.fi/ymparistovirasto/jateneuvonta/ravinnepankki/ havikkiruoka.html. Accessed 16.12.2017.

Schön, D., Rein, M. (1994). Frame reflection: Toward the resolution of interactable policy controversies. BasicBooks.

Servica (2017). Ylijäämäruoan myynti. https://servica.fi/palvelumme/ ruokapalvelut/. Accessed 16.12.2017.

Silvennoinen, K., Koivupuro, H-K., Katajajuuri, J-M., Jalkanen, L., Reinikainen, A. (2012). Ruokahävikki suomalaisessa ruokaketjussa: Foodspill 2010-2012 -hankkeen loppuraportti. MTT Raportti 41. Jokioinen: Maa- ja elintarviketalouden tutkimuskeskus MTT.

Silvennoinen, K., Katajajuuri, J.-M., Hartikainen, H., Heikkilä, L., \& Reinikainen, A. (2016). Food waste and related climate impacts in Finland. In A. Paloviita \& M. Järvelä (Eds.), Climate change adaptation and food supply chain management (pp. 183-193). Oxon: Routledge.

Sonnino, R., \& McWilliam, S. (2011). Food waste, catering practices and public procurement: A case study of hospital food systems in Wales. Food Policy, 36, 823-829.

Sonnino, R., Torres, C. L., \& Schneider, S. (2014). Reflexive governance for food security: The example of school feeding in Brazil. Journal of Rural Studies, 36, 1-12.

Testa, F., Iraldo, F., Frey, M., \& Daddi, T. (2012). What factors influence the uptake of GPP (green public procurement) practices? New evidence from an Italian survey. Ecological Economics, 82, 88-96. 
Timmer, P. C. (2008). Do supermarkets change the food policy agenda? World Development, 37(11), 1812-1819.

Tuusula (2017). Ylijäämäruoan myynti. https://www.tuusula.fi/sivu. tmpl?sivu_id=7150. Accessed 16.12.2017.

VARAM (2016). Vispārīgās vadlīnijas zaḷā publiskā iepirkuma piemērošanai. December 7, 2017. Available at: http://www.varam. gov.lv/lat/darbibas_veidi/zalais_publiskais_iepirkums/?doc=22769. Accessed 12.08.2018.

Vītola. (2016). Par bērnu veǵetāru ēdināšanu PVD skolai uzliek naudas sodu un liek barot bērnus ar gal̦u. October 19, 2016. Available at: https://skaties.lv/zinas/latvija/sabiedriba/par-bernu-vegetaruedinasanu-pvd-skolai-uzliek-naudas-sodu-un-liek-barot-bernus-argalu/. Accessed 12.08.2018.

VRN. (2008). Kouluruokailusuositus. Valtion ravitsemusneuvottelukunta: Helsinki.

VRN (2014). Terveyttä ruoasta: Suomalaiset ravitsemussuositukset 2014. 2nd revised ed. Helsinki: Valtion Ravitsemusneuvottelukunta.

Yle (2013). Jyväskylä: Yli jääneen kouluruoan myynti ei riko lakia. Kotimaa, 25.9.2013. https://yle.fi/uutiset/3-6848406. Accessed 29. 12.2017 .

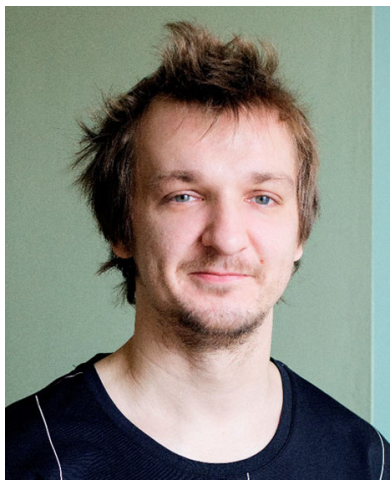

Mikelis Grivins dr.soc., is a researcher at the Baltic Studies Centre in Latvia. Grivins has been involved in studying foraging, agro-food systems and sustainability transition in Central and Eastern Europe. His current research addresses the role of wild product gathering and untapped potential of non-timber forest products in the European countryside. Grivins is the chair of the Latvian Sociological association and the convenor of the panEuropean research study group "Alternative food supply networks in Central and Eastern Europe".
Also he is a member of the Expert Committee in Humanities and Social Sciences of the Latvian Council of Science (2013-2018) and supervisor of $\mathrm{PhD}$ students, post-doctoral researchers and Marie Sklodowska-Curie early career researcher within PUREFOOD (2010-2014) and SUSPLACE (2015-2019) training programmes.

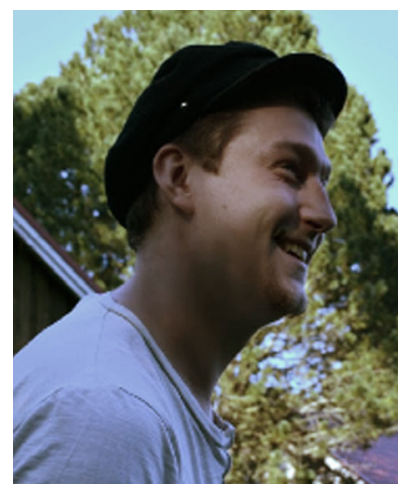

Ville Tikka is a $\mathrm{PhD}$ student at the University of Jyväskylä, Finland. $\mathrm{He}$ is currently working on his dissertation on novel protein sources, focusing on gendered processes, interpretations and values.

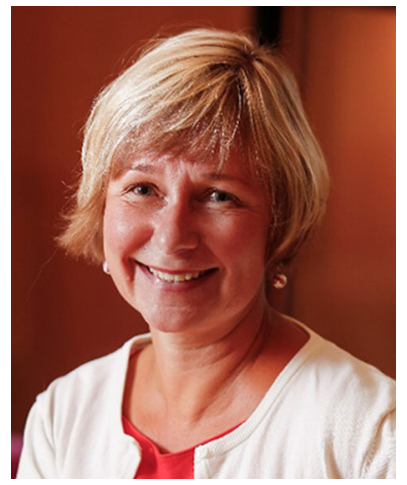

Tiina Silvasti is a Professor of Social and Public Policy in the Department of Social Sciences and Philosophy at the University of Jyväskylä, Finland. She has, in particular, studied the social consequences of structural change in agriculture. Her recent research interests focus on food system studies, especially First World hunger.

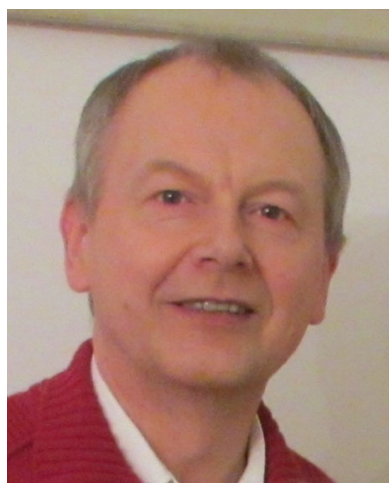

Talis Tisenkopfs is a director of the Baltic Studies Centre and director of the $\mathrm{PhD}$ programme in sociology at the University of Latvia. His research focuses on innovation processes in agriculture and food systems, food security, food supply chains, and postsocialist transformation of agriculture and rural areas. $\mathrm{He}$ is a Member of the COST Scientific Committee (2015-2019), vicepresident of the European Society for Rural Sociology (2015-2017) and former independent expert on agricultural knowledge and innovation systems at the European Commission, Directorate E: Biotechnologies, Agriculture, Food (2010-2011). Former editor-in-chief of Latvia Human Development Reports, published by UNDP. He is the Latvian team leader of 23 EU Framework and Horizon 2020 projects including AgriLink, ROBUST, PLAID, SALSA, SUFISA, TRANSMANGO and others. 